\title{
Assessment of Saudi Parents' Beliefs and Behaviors towards Management of Child Fever in Saudi Arabia-A Cross-Sectional Study
}

\author{
Mohamed N. Al Arifi * and Abdulrahman Alwhaibi (DD
}

Citation: Al Arifi, M.N.; Alwhaibi, A Assessment of Saudi Parents' Beliefs and Behaviors towards Management of Child Fever in Saudi Arabia-A Cross-Sectional Study. Int. J. Environ. Res. Public Health 2021, 18, 5217.

https://doi.org/10.3390/ ijerph18105217

Academic Editor: Paul B. Tchounwou

Received: 19 April 2021

Accepted: 10 May 2021

Published: 14 May 2021

Publisher's Note: MDPI stays neutral with regard to jurisdictional claims in published maps and institutional affiliations.

Copyright: (c) 2021 by the authors. Licensee MDPI, Basel, Switzerland. This article is an open access article distributed under the terms and conditions of the Creative Commons Attribution (CC BY) license (https:// creativecommons.org/licenses/by/ $4.0 /)$.
Department of Clinical Pharmacy, College of Pharmacy, King Saud University, Riyadh 11451, Saudi Arabia; aalwhaibi@KSU.EDU.SA

* Correspondence: malarifi@ksu.edu.sa

\begin{abstract}
Objective: Fever alone can lead to rare serious complications in children, such as febrile seizures. The aim of this study is to assess the knowledge, beliefs, and behavior of parents toward fever and its management. Methods: A cross-sectional study using an online questionnaire was applied over a period of 3 months, from January to March 2018, to parents who were living in Saudi Arabia. The inclusion criteria were a parent who is a resident of Saudi Arabia, with at least one child aged 6 years or less, while incomplete questionnaires, having a child aged more than 6 years, or parents who were not living in Saudi Arabia were excluded. Results: A total of 656 parents completed the questionnaire. More than two-thirds of the subjects were female, the majority of whom were aged between 25-33 years old. The best-reported place to measure the temperature of children was the armpit $(46 \%)$, followed by the ear $(28 \%)$ and the mouth $(10.7 \%)$. More than half of the parents considered their children feverish at a temperature of $38^{\circ} \mathrm{C}$. The majority of parents $(79.7 \%)$ reported that the most serious side effects of fever were seizure, brain damage (39.3\%), coma $(29.9 \%)$, dehydration $(29.7 \%)$, and death $(25 \%)$. The most common method used to measure a child's temperature was an electronic thermometer $(62.3 \%)$. The most common antipyretic was paracetamol $(84.5 \%)$. Conclusions: Our study demonstrates the good knowledge of parents in identifying a feverish temperature using the recommended route and tools for measuring body temperature.
\end{abstract}

Keywords: Saudi parents; beliefs and behaviors; fever; Saudi Arabia

\section{Introduction}

Despite that fever alone can lead to rare serious complications in children, such as febrile seizures, it is considered a self-manageable condition that can be managed at home with nonpharmacological or pharmacological (over-the-counter) medications [1]. However, overloaded visits to emergency medicine departments, pediatricians, and primary care offices are noticeable, possibly due to the vast spread of "fever phobia" phenomena among parents and healthcare providers [2-10]. The concept of "fever phobia" was first introduced in 1980 to detail parents' spurious fright of fever and to highlight erroneous beliefs of its management [11]. The fear and misconception of fever were not solely restricted to parents. It includes other healthcare providers $[12,13]$. While earlier reports have revealed that fever has positive effects and is a sign of the significant improvement of the immune system, negative perceptions, like fears of febrile seizures, have caused health fever phobia, which remains challenging. Physicians continue to reduce low-grade fever without other symptoms and recommend various kinds of antipyretics to feverish children as initial treatment $[5,14]$. Several health professional agencies have published guidelines for healthcare providers and parents to instruct them on how to detect, manage, and monitor fever in children in order to halt the unrealistic fear of fever $[15,16]$. However, numerous reports from parents and other healthcare providers have ensured the insufficient 
knowledge, inappropriate attitude, misleading behaviors, and false beliefs of fever in children in different communities [4-13].

A previous study by AlAteeq et al. among Saudi parents evaluated the knowledge and practice in the home management of fever and indicated poor knowledge and practice with regards to child fever. In addition to this previous finding, the authors concluded the overuse of nonprescribed fever medication and the possible waste of health resources [17]. Similarly, another study by Hussain et al. indicated many misconceptions regarding fever among the majority of parents. In addition to this, Saudi parents have demonstrated undue fear of consequent body damage from fever and also believe that antibiotics can reduce high temperature [18]. One of the ultimate goals of any local healthcare system is to provide appropriate care for children and enough educational knowledge for their parents, in the same manner as international and other healthcare systems, about the most common illnesses, such as fever. To accomplish such a goal and to release evident-based instructions that comply with different societies, the assessment of the knowledge, attitude, and beliefs of the public toward fever and its management is required. Although several studies in different communities over the years have demonstrated the unrealistic fear and misconception of fever, no similar study has been conducted in Saudi Arabia [6,7,10,19]. The aim of this study is to assess the knowledge, beliefs, and behavior of parents toward fever and its management.

\section{Materials and Methods}

A cross-sectional study using an online questionnaire was applied. It was carried out during the period of January to March 2018 among Saudi parents who were living in Saudi Arabia. The inclusion criteria were a parent who is a resident of Saudi Arabia, living in Saudi during the time, with at least one child aged 6 years or less; exclusion criteria were incomplete questionnaires, having a child aged more than 6 years, and parents who were not living in Saudi Arabia at the time.

\subsection{Development and Validation and Content of Questionnaires}

A survey questionnaire was developed based on previous studies to assess the knowledge, attitude, and practice of parents towards fever in children and its management (KAP) $[17,18,20]$. The KAP survey contained questions about the methods utilized for measuring body temperature, frequency of checking the temperature, attitude towards the complications of fever, methods to select the appropriate drug or doses administered, attitude towards alternating drugs, and practices in obtaining and using antibiotic drugs. In addition, this study used questions to assess the parents' sociodemographic data. The questionnaire was translated to the Arabic language by an independent professional translator using the forward-back translation procedure [21]; an expert in the field was requested to comment independently on the suitability of the questions in order to assess the validity of the questionnaire. After that, the questionnaire was validated using 10 randomly selected parents; the reliability test was determined through Cronbach's alpha, and it was found to be 0.72 .

\subsection{Sample Size and Population}

The sample size for this study was calculated using an online sample size calculator (http:/ / www.raosoft.com/samplesize.html, accessed on 13 May 2021) by assuming a larger population size with a margin of error of $\pm 5 \%$ and a confidence level of $95 \%$, which resulted in a sample of 384 individuals [22].

\subsection{Ethical Consideration}

The present investigation was conducted according to the guidelines of the Checklist for Reporting Results of Internet E-Surveys (CHERRIES) [23]. In the survey questionnaires, there was a short paragraph stating the objective of the research and its importance and a statement on participation in the research being mandatory and participants having the full 
right to withdraw from the study at any point in time. Participants were also assured that their data would be used only for research purposes and would be considered confidential. Participants were also given confidence that there was no risk associated with participation in this study. Additionally, participants' informed consent was obtained prior to answering the survey questions; they were also requested to provide authentic answers.

Data Extraction and Management

Data extraction is a crucial step in the research process and involves careful examination of completed and incompletely answered questionnaires [24]. For the current study, the data were checked for accuracy and completeness. Missing responses, incomplete responses, and invalid responses were excluded from the study, as shown in Figure 1.

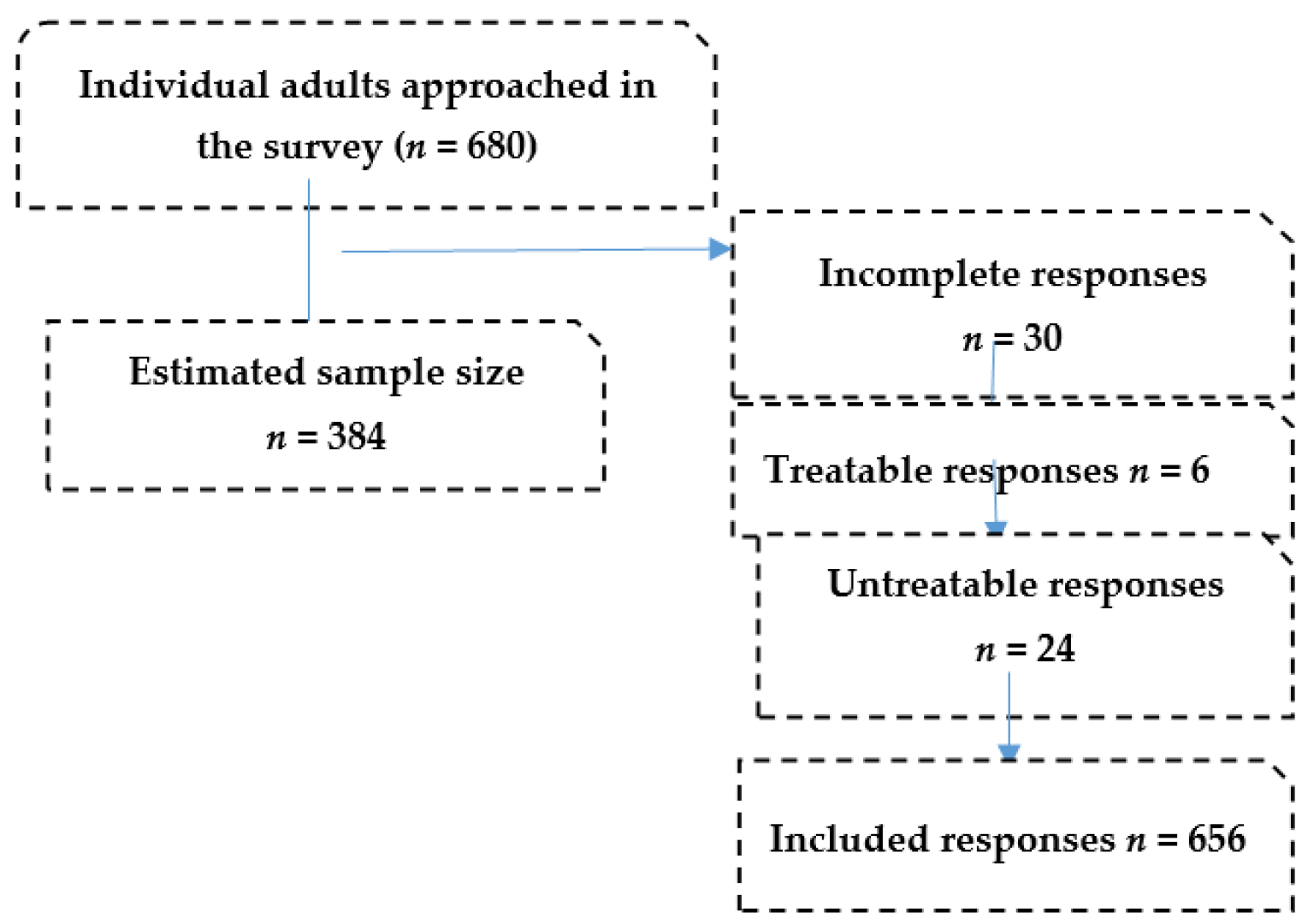

Figure 1. Flowchart of the responses.

\subsection{Data Analysis}

Descriptive statistics, including percentages, means, and frequency distributions, were used for each variable. Statistical Package for Social Sciences version 22.0 (SPSS Inc., Chicago, IL, USA) was used for statistical computations.

\section{Results}

In this study, a total of 656 parents completed the questionnaire. More than two-thirds of the subjects were female, with a majority of parents' age ranging from 25 to 33 years. The youngest child of about $21 \%$ of the parents surveyed was one year of age. Most of the parents had a university education. The details of the demographic data are summarized in Table 1. 
Table 1. Demographic data of respondents $(n=656)$.

\begin{tabular}{|c|c|c|c|}
\hline \multicolumn{2}{|c|}{ Variables } & \multirow{3}{*}{$\begin{array}{c}\text { Number } \\
248 \\
408\end{array}$} & \multirow{3}{*}{$\begin{array}{c}\text { Percentages } \\
37.8 \\
62.2\end{array}$} \\
\hline & Male & & \\
\hline Gender & Female & & \\
\hline \multirow{6}{*}{ Age of parents } & Less than 18 & 23 & 3.55 \\
\hline & 18-24 years & 152 & 23.2 \\
\hline & $25-33$ years & 258 & 39.3 \\
\hline & $34-51$ years & 215 & 32.8 \\
\hline & $52-64$ years & 7 & 1.1 \\
\hline & More than 65 & 1 & 0.2 \\
\hline \multirow{7}{*}{$\begin{array}{c}\text { Age of youngest } \\
\text { child }\end{array}$} & less than 1 year & 115 & 17.5 \\
\hline & 1 & 137 & 20.9 \\
\hline & 2 & 109 & 16.6 \\
\hline & 3 & 104 & 15.9 \\
\hline & 4 & 92 & 14 \\
\hline & 5 & 89 & 13.6 \\
\hline & 6 & 10 & 1.5 \\
\hline \multirow{5}{*}{ Education level } & Illiterate & 5 & 0.8 \\
\hline & Primary/secondary school & 28 & 4.3 \\
\hline & High school & 144 & 22 \\
\hline & University & 432 & 65.9 \\
\hline & Postgraduate & 47 & 7.2 \\
\hline \multirow{3}{*}{ Insurance } & None & 266 & 40.5 \\
\hline & General & 254 & 38.7 \\
\hline & Private & 136 & 20.7 \\
\hline
\end{tabular}

\subsection{Attitude of Parents towards Fever and Its Management}

The most common place to measure the temperature of children was the armpit (46\%), followed by the ear ( $28 \%)$, mouth $(10.7 \%)$, and then by hands or feet $(6.1 \%)$. In this surveyed study, nearly $47 \%$ of parents thought that $36^{\circ} \mathrm{C}$ was the normal body temperature. More than half of parents considered their children feverish at a temperature of $38^{\circ} \mathrm{C}$. In this study, only $20 \%$ of parents stated using the rectal route for medication; however, the reasons for using the rectal route were its high efficacy $(16.2 \%)$, child refusal $(12 \%)$, the belief of it being more practical $(6.3 \%)$, and the presence of vomiting $(5.3 \%)$.

The majority of parents $(79.7 \%)$ reported that the most serious side effects of fever were seizure, followed by brain damage (39.3\%), coma (29.9\%), dehydration $(29.7 \%)$, and death $(25 \%)$, as presented in Table 2.

Table 2. Attitude of parents towards fever and its management.

\begin{tabular}{|c|c|c|c|}
\hline \multicolumn{2}{|c|}{ Variables } & \multirow{2}{*}{$\begin{array}{c}\text { Number } \\
22\end{array}$} & \multirow{2}{*}{$\begin{array}{c}\text { Percentages } \\
3.4\end{array}$} \\
\hline \multirow{6}{*}{$\begin{array}{l}\text { The most common } \\
\text { places temperature } \\
\text { is measured }\end{array}$} & The rectum & & \\
\hline & The mouth & 70 & 10.7 \\
\hline & The armpit & 184 & 28 \\
\hline & The ear & 302 & 46 \\
\hline & by hands or feet & 40 & 6.1 \\
\hline & I don't know & 38 & 5.8 \\
\hline \multirow{7}{*}{$\begin{array}{l}\text { Opinions towards } \\
\text { normal body } \\
\text { temperature }\end{array}$} & $36^{\circ} \mathrm{C}$ & 311 & 47.4 \\
\hline & $37^{\circ} \mathrm{C}$ & 291 & 44.4 \\
\hline & $38^{\circ} \mathrm{C}$ & 11 & 1.7 \\
\hline & $39^{\circ} \mathrm{C}$ & 1 & 0.2 \\
\hline & $40{ }^{\circ} \mathrm{C}$ & 1 & 0.2 \\
\hline & $41^{\circ} \mathrm{C}$ & 1 & 0.2 \\
\hline & I don't know & 40 & 6.1 \\
\hline
\end{tabular}


Table 2. Cont.

\begin{tabular}{|c|c|c|c|}
\hline & Variables & Number & Percentages \\
\hline \multirow{7}{*}{$\begin{array}{l}\text { Opinions towards } \\
\text { fever temperature }\end{array}$} & $36^{\circ} \mathrm{C}$ & 4 & 0.6 \\
\hline & $37^{\circ} \mathrm{C}$ & 37 & 5.6 \\
\hline & $38^{\circ} \mathrm{C}$ & 359 & 54.7 \\
\hline & $39^{\circ} \mathrm{C}$ & 161 & 24.5 \\
\hline & $40{ }^{\circ} \mathrm{C}$ & 65 & 9.9 \\
\hline & $41^{\circ} \mathrm{C}$ & 8 & 1.2 \\
\hline & I don't know & 22 & 3.4 \\
\hline \multirow{7}{*}{$\begin{array}{c}\text { Opinions about what } \\
\text { temperature needs a } \\
\text { dose of drugs }\end{array}$} & $36^{\circ} \mathrm{C}$ & 6 & 0.9 \\
\hline & $37^{\circ} \mathrm{C}$ & 55 & 8.4 \\
\hline & $38^{\circ} \mathrm{C}$ & 392 & 59.8 \\
\hline & $39^{\circ} \mathrm{C}$ & 156 & 23.8 \\
\hline & $40{ }^{\circ} \mathrm{C}$ & 26 & 4 \\
\hline & $41^{\circ} \mathrm{C}$ & 4 & 0.6 \\
\hline & I don't know & 17 & 2.6 \\
\hline \multirow{5}{*}{$\begin{array}{c}\text { Reasons for } \\
\text { favoring the } \\
\text { administration of the } \\
\text { medication rectally }\end{array}$} & More efficacy & 106 & 16.2 \\
\hline & More practical & 41 & 6.3 \\
\hline & Because of vomiting & 35 & 5.3 \\
\hline & Because of child refusal & 79 & 12 \\
\hline & According to a physician's prescription & 18 & 2.7 \\
\hline \multirow{6}{*}{$\begin{array}{l}\text { Complications of } \\
\text { fever }\end{array}$} & Brain damage & 258 & 39.3 \\
\hline & Seizure & 523 & 79.7 \\
\hline & Death & 164 & 25 \\
\hline & Coma & 196 & 29.9 \\
\hline & Dehydration & 195 & 29.7 \\
\hline & None & 26 & 4 \\
\hline
\end{tabular}

\subsection{Knowledge of Parents of Methods in Managing Fever}

In this study, the most common method used to measure a child's temperature was an electronic thermometer (62.3\%), followed by hands (32.2\%), and a mercury-in-glass thermometer (3.5\%) (Table 3). Additionally, this study assessed the knowledge of parents on drug therapy and other remedies to treat fever (Table 3). However, the most common antipyretics were paracetamol (84.5\%) followed by antibiotics (19.4\%) and ibuprofen (10.5\%). On the other hand, the majority of parents $(78.4 \%)$ also used cold-sponging to treat fever. To determine the appropriate dose of antipyretic medication, about $77 \%$ of parents stated that they normally use the spoon syringe provided with the drug for specific measurement.

Table 3. Knowledge of parents' methods in managing childhood fever.

\begin{tabular}{|c|c|c|c|}
\hline & Variables & Number & Percentage \\
\hline \multirow{5}{*}{$\begin{array}{l}\text { Method for } \\
\text { measuring } \\
\text { temperature }\end{array}$} & Hand & 211 & 32.2 \\
\hline & Electronic thermometer & 409 & 62.3 \\
\hline & Mercury-in-glass thermometer & 23 & 3.5 \\
\hline & I do not check my child's temperature & 7 & 1.1 \\
\hline & I do not know & 6 & 0.9 \\
\hline \multirow{5}{*}{$\begin{array}{l}\text { Frequency of } \\
\text { measuring } \\
\text { temperature, } \\
\text { every }\end{array}$} & less than $15 \mathrm{~min}$ & 83 & 12.7 \\
\hline & $15-30 \mathrm{~min}$ & 227 & 34.6 \\
\hline & $30 \mathrm{~min}-1 \mathrm{~h}$ & 169 & 25.8 \\
\hline & $1-2 \mathrm{~h}$ & 122 & 18.6 \\
\hline & More than $2 \mathrm{~h}$ & 55 & 8.4 \\
\hline
\end{tabular}


Table 3. Cont.

\begin{tabular}{cccc}
\hline & Variables & Number & Percentage \\
\hline & Acetaminophen & 554 & 84.5 \\
Drugs for fever & Ibuprofen & 69 & 10.5 \\
& Aspirin & 14 & 2.1 \\
& Antibiotics & 127 & 19.4 \\
& Other & 29 & 4.4 \\
\hline Remedies used in & Cold sponging & 514 & 78.4 \\
addition to drugs & Ice pack & 5 & 0.8 \\
& Tepid sponging & 89 & 13.6 \\
& I use drugs only & 29 & 4.4 \\
Site of medication & Oral & 19 & 2.9 \\
administration & Rectal & 521 & 79.4 \\
\hline & Teaspoon & 135 & 20.6 \\
\hline Tools used to & Specific measurement spoon or syringe & 53 & 8.1 \\
administer the & provided with the drug & 505 & 77 \\
medication & Measuring spoon or syringe of other drugs & 98 & 14.9 \\
\hline
\end{tabular}

\subsection{Practice of Parents in Fever Treatment}

Table 4 shows the practice of parents regarding fever and its treatment. About $60 \%$ of parents used pharmacological or nonpharmacological therapy if the temperature was $38{ }^{\circ} \mathrm{C}$. In addition, $46 \%$ of parents stated that they only called the doctor if the child's temperature reached $39{ }^{\circ} \mathrm{C}$, while $37.3 \%$ of parents called the doctor for a temperature of $38^{\circ} \mathrm{C}$.

Table 4. Practice of parents with regard to fever.

\begin{tabular}{|c|c|c|c|}
\hline & Variables & Number & Percentage \\
\hline \multirow{7}{*}{$\begin{array}{l}\text { When treatment is } \\
\text { administered }\end{array}$} & $36^{\circ} \mathrm{C}$ & 6 & 0.9 \\
\hline & $37^{\circ} \mathrm{C}$ & 55 & 8.4 \\
\hline & $38^{\circ} \mathrm{C}$ & 392 & 59.8 \\
\hline & $39^{\circ} \mathrm{C}$ & 156 & 23.8 \\
\hline & $40{ }^{\circ} \mathrm{C}$ & 26 & 4 \\
\hline & $41^{\circ} \mathrm{C}$ & 4 & 0.6 \\
\hline & I don't know & 17 & 2.6 \\
\hline \multirow{6}{*}{ When doctor is called } & $38^{\circ} \mathrm{C}$ & 285 & 37.3 \\
\hline & $39^{\circ} \mathrm{C}$ & 302 & 46 \\
\hline & $40^{\circ} \mathrm{C}$ & 91 & 13.9 \\
\hline & $41^{\circ} \mathrm{C}$ & 12 & 1.8 \\
\hline & $42{ }^{\circ} \mathrm{C}$ & 1 & 0.2 \\
\hline & $43^{\circ} \mathrm{C}$ & 5 & \\
\hline \multirow{7}{*}{$\begin{array}{c}\text { The right antipyretic } \\
\text { drug based on }\end{array}$} & Previous advice from the pediatrician & 346 & 52.7 \\
\hline & Consultation of pharmacist & 126 & 19.2 \\
\hline & Consultation of other persons & 18 & 2.7 \\
\hline & Information collected by media & 19 & 2.9 \\
\hline & I decide by myself & 39 & 5.9 \\
\hline & I call my pediatrician & 95 & 14.5 \\
\hline & Other & 13 & 2 \\
\hline \multirow{7}{*}{$\begin{array}{l}\text { Calculation of the } \\
\text { appropriate dose of } \\
\text { the fever-lowering } \\
\text { drug based on }\end{array}$} & Previous advice from the pediatrician & 267 & 40.7 \\
\hline & Reading the package leaflet & 220 & 33.5 \\
\hline & Consultation of the pharmacist & 85 & 13 \\
\hline & Media & 4 & 0.6 \\
\hline & I decide by myself & 10 & 1.5 \\
\hline & I call my pediatrician & 65 & 9.9 \\
\hline & Other & 5 & 0.8 \\
\hline
\end{tabular}


Table 4. Cont.

\begin{tabular}{cccc}
\hline & Variables & Number & Percentage \\
\hline & Age & 346 & 52.7 \\
To give a & Sex & 126 & 19.2 \\
fever-lowering drug, & Weight & 18 & 2.7 \\
you consider & Height & 19 & 2.9 \\
& Severity of fever & 39 & 5.9 \\
& Severity of illness & 95 & 14.5 \\
& Nothing & 13 & 2 \\
\hline
\end{tabular}

This study found that the antipyretic drug selection was based on previous prescriptions for the same child (52.7\%), followed by pharmacists' recommendations $(19.2 \%)$ and pediatricians' recommendations $(14.5 \%)$. In order to calculate the appropriate dose of the antipyretic drug to be administered to the feverish child, around $40.7 \%$ of parents would give a dose based on the previously prescribed dose, information in the package leaflet $(33.5 \%)$, or a pharmacist's recommendation $(13 \%)$ (Table 4$)$.

\subsection{Attitude of Parents towards Antibiotic Use for Fever}

Approximately $14.2 \%$ of participating parents reported using antibiotics when their child had a fever, while $17.7 \%$ would use it when they suspected infection. Regardless of the reason for utilizing antibiotics, either for fever or suspected infection, about $13 \%$ of parents would obtain antibiotics without a physician's prescription. Some parents $(11.7 \%)$ thought that antibiotics should be prescribed to all children who develop fever, and $7.9 \%$ would be insistent on prescribing some antibiotics to their feverish children. Table 5 details the parents' attitude towards antibiotic use for feverish children.

Table 5. Attitude of parents towards antibiotic use for fever.

\begin{tabular}{|c|c|c|c|}
\hline \multicolumn{2}{|l|}{ Variables } & \multirow{2}{*}{$\frac{\text { Number }}{93}$} & \multirow{2}{*}{$\frac{\text { Percentage }}{14.2}$} \\
\hline \multirow{5}{*}{ Antibiotic use } & Child has fever & & \\
\hline & Suspect an infection & 116 & 17.7 \\
\hline & Doctor's prescription & 389 & 59.3 \\
\hline & Advertisements & 4 & 0.6 \\
\hline & All above & 54 & 8.2 \\
\hline \multirow{5}{*}{ Purchase an antibiotic from pharmacy } & Have prescription & 514 & 78.4 \\
\hline & Myself & 85 & 13 \\
\hline & Someone & 14 & 2.1 \\
\hline & Internet & 8 & 1.2 \\
\hline & Other & 35 & 5.3 \\
\hline \multirow{2}{*}{$\begin{array}{l}\text { In general, would you give antibiotics to your } \\
\text { unwell child without consulting a physician }\end{array}$} & Yes & 101 & 15.4 \\
\hline & No & 555 & 84.6 \\
\hline \multirow{2}{*}{$\begin{array}{l}\text { In general, would you be insistent in prescribing } \\
\text { some antibiotics to your child }\end{array}$} & Yes & 52 & 7.9 \\
\hline & No & 604 & 92.1 \\
\hline \multirow{2}{*}{$\begin{array}{l}\text { In general, would you use antibiotics based on a } \\
\text { pharmacist's consultation? }\end{array}$} & Yes & 309 & 47.1 \\
\hline & No & 347 & 52.9 \\
\hline \multirow{2}{*}{$\begin{array}{l}\text { Do you think antibiotics should be prescribed to } \\
\text { all children who develop a fever? }\end{array}$} & Yes & 77 & 11.7 \\
\hline & No & 579 & 88.3 \\
\hline
\end{tabular}

\section{Discussion}

Although there is no consensus on a single value to define fever since it differs based on the route of measurement, the thresholds of $\geq 38^{\circ} \mathrm{C}$ for babies younger than 3 months and $\geq 39{ }^{\circ} \mathrm{C}$ for children who are 3 months and older are considered the feverish temperature $[16,20]$. Almost $92 \%$ of our participants believed that a temperature between $36-37.9^{\circ} \mathrm{C}$ is the normal body temperature, and around $79.2 \%$ reported the fever tempera- 
ture correctly at $38-39^{\circ} \mathrm{C}$. These results are in contrast to $34.3 \%$ of Australian parents who reported the fever temperature correctly at $38-39^{\circ} \mathrm{C}$, while our results seem comparable with caregivers in other communities [9]. The correct reporting of fever temperature among Jordanian, Greek, and Turkish parents were $78.25 \%, 66.1 \%$, and $57.8 \%$, respectively $[7,20,25]$. Two other local studies that focused solely on the parents who visited the emergency room or clinics for their febrile children revealed that the knowledge of the correct degree of fever had risen from $46 \%$ to $64 \%$ from 2000 to 2015 [25,26]. The high knowledge of fever temperature among parents in Saudi Arabia and the surrounding regions, specifically in recent years, may be the result of the frequent incident attacks of viruses causing fever, such as dengue fever, swine or avian influenza, or Middle East respiratory syndrome (MERS).

According to the recommendations, a digital thermometer device is the preferred tool to measure children's core temperature $[14,26,27]$. The axillary method is the preferred measurement for children $<4$ weeks and all children, while the tympanic method seems to be the second preferred measurement for children $\geq 4$ weeks. The oral measurement of temperature is not feasible in children because it is influenced by many factors, such food or liquid intake and patient cooperation for measurement [26-28]. The rectal method is not recommended to be used by caregivers due to its (1) invasive application, (2) slow detection in core temperature changes, (3) inaccuracy in the presence of blood or feces, and (4) risk of bacterial contamination or rectal perforation [29-32]. The results of the participating parents showed some consistency with national recommendations. Most of our participants used an electronic thermometer (62.3\%) to measure body temperature; however, a slightly high number of parents (32.2\%) still used their hands for fever detection. The tympanic method $(46 \%)$ and the axillary (precisely in armpits area) method (28\%) were the most-reported methods for fever detection, while the oral (10.7\%) and rectal (3.4\%) methods were the least-reported methods. In comparison with other caregivers in different communities, temperature-taking in the armpits of children was the commonly reported method among Greek (95.4\%), Turkish (91.2\%), Italian $(82 \%)$, Emirati $(60 \%)$, and Jordanian $(43.2 \%)$ caregivers $[4,7,20,25,28]$. Although parents used the most recommended route for measuring body temperature, the accuracy and technique of measuring children's body temperature by parents is still an essential concern [33].

Regardless of the route of administration, acetaminophen and ibuprofen are the recommended antipyretics for feverish children [34]. Some societies prefer an oral administration over a rectal administration of acetaminophen due to delay and inconstant absorption and the inaccuracy of the dose [26,27]. Most guidelines use weight-based dosing of acetaminophen and ibuprofen for children with fever, and some of them emphasize utilizing only the measuring devices provided with medications [35,36]. Cold or tepid sponging is not recommended since its evidence of efficacy is limited, its action is not directed toward the heat center, and its adverse effects of shivering and discomfort have been reported. Acetaminophen was used by $84.5 \%$ of our participants, while only $10.5 \%$ of them used ibuprofen. The oral route $(79.4 \%)$ was the preferred route of administration, and the measuring devices provided with medications $(77 \%)$ were used frequently by parents to measure the oral dose. Although most of the participating parents used the recommend antipyretics with the preferred route and measurements, around $78.4 \%$ and $13.6 \%$ were using cold and tepid sponging, respectively. In addition, about $19.4 \%$ of the participants used antibiotics as their choice for treating fever in children. In general, the use of antibiotics in Saudi Arabia without prescription for different issues seems to be trending downwards, from $78.7 \%$ in 2014 to $43.4 \%$ in 2017 [37,38], likely due to extensive education on the harmful effects of using antibiotics without prescription and the implementation of fines and penalties for breaking the law, implemented by the Saudi Ministry of Health, that prevents the sales of antibiotics without prescription [39,40]. According to a recent study that assessed the self-medication of antibiotics among Saudis in 2017, almost 29\% reported using antibiotics for fever, while, in our study, only $14.2 \%$ of parents were using antibiotics for feverish children; around 13\% of them were purchasing antibiotics directly from the pharmacies [35,36]. This is comparable to Jordanian parents $(14 \%)$ who use antibiotics for 
their feverish children [20]. Although the monetary fines and penalties have diminished the sales of antibiotics without prescription, education on the use of antibiotics should be directed towards the public since there are still some parents $(7.9 \%)$ who are insistent on prescribing antibiotics to their child. Although the online-conducted survey could be a limitation since some segments of the population cannot be approached, it seems to be a convenient method due to the high literacy rate and high usage of social media and chat applications [34,35]. Our study is not focused on the public, and it is only restricted to parents who have visited clinics or emergency departments with their feverish children because the aim of the study was to investigate the knowledge, practice, attitude, and belief of parents towards fever, especially from a Saudi mother's perspective.

\section{Conclusions}

Our study has demonstrated the good knowledge of parents in identifying feverish temperatures using the recommended route and tools for measuring body temperature and selecting the appropriate antipyretic. However, constructive easy-to-read guidance, directed to parents for the management of feverish children, should be formulated and implemented by local agencies with a focus on the use of preferred nonpharmacological interventions, ways of appropriate utilization of various measuring devices, and the avoidance of antibiotics as a management technique for fever alone.

Author Contributions: Conceptualization, M.N.A.A.; Data curation, M.N.A.A. and A.A.; Formal analysis, M.N.A.A. and A.A.; Funding acquisition, M.N.A.A. and A.A.; Investigation, M.N.A.A. and A.A.; Methodology, M.N.A.A. and A.A.; Project administration, M.N.A.A. and A.A.; Software, M.N.A.A. and A.A.; Supervision, M.N.A.A.; Visualization, A.A.; Writing-original draft, M.N.A.A. and A.A.; Writing-review \& editing, M.N.A.A. and A.A. All authors have read and agreed to the published version of the manuscript.

Funding: This research did not receive any specific grant from funding agencies in public, commercial, or not-for-profit sectors.

Institutional Review Board Statement: The study was exempted from the Institutional Review Board. Although study was conducted according to the guidelines of the Declaration of Helsinki.

Informed Consent Statement: Informed consent was obtained from all subjects involved in the study.

Data Availability Statement: Data will be available upon request from the corresponding author of the study.

Acknowledgments: The Authors extend their appreciation to the Research Center at King Saud University College of Pharmacy for supporting this work.

Conflicts of Interest: The authors declare no conflict of interest.

\section{References}

1. Lemay, V.; Feret, B. Chapter 6: Fever. In Handbook of Nonprescription Drugs: An Interactive Approach to Self-Care, 19th ed.; Krinsky, D., Ed.; American Pharmacists Association: Washington, DC, USA, 2017.

2. Cohee, L.M.; Crocetti, M.T.; Serwint, J.R.; Sabath, B.; Kapoor, S. Ethnic differences in parental perceptions and management of child-hood fever. Clin. Pediatr. 2010, 49, 221-227. [CrossRef] [PubMed]

3. Niska, R.; Bhuiya, F.; Xu, J. National Hospital Ambulatory Medical Care Survey: 2011 Emergency Department Summary Tables. Available online: http://www.cdc.gov/nchs/data/ahcd/nhamcs_emergency/2011_ed_web_tables.pdf (accessed on 10 April 2019).

4. Betz, M.G.; Grunfeld, A.F. Fever phobia in the emergency department: A survey of childrens caregivers. Eur. J. Emerg. Med. 2006, 13, 129-133. [CrossRef]

5. Crocetti, M.; Moghbeli, N.; Serwint, J. Fever Phobia Revisited: Have Parental Misconceptions About Fever Changed in 20 Years? Pediatrics 2001, 107, 1241-1246. [CrossRef]

6. Crocetti, M.; Sabath, B.; Cranmer, L.; Gubser, S.; Dooley, D. Knowledge and management of fever among Latino par-ents. Clin. Pediatr. 2009, 48, 183-189. [CrossRef]

7. Matziou, V.; Brokalaki, H.; Kyritsi, H.; Perdikaris, P.; Gymnopoulou, E.; Merkouris, A. What Greek mothers know about evaluation and treatment of fever in children: An interview study. Int. J. Nurs. Stud. 2008, 45, 829-836. [CrossRef] 
8. Rupe, A.; Ahlers-Schmidt, C.R.; Wittler, R. A Comparison of Perceptions of Fever and Fever Phobia by Ethnicity. Clin. Pediatr. 2009, 49, 172-176. [CrossRef] [PubMed]

9. Walsh, A.; Edwards, H.; Fraser, J. Influences on parents' fever management: Beliefs, experiences and information sources. J. Clin. Nurs. 2007, 16, 2331-2340. [CrossRef]

10. Langer, T.; Pfeifer, M.; Soenmez, A.; Tarhan, B.; Jeschke, E.; Ostermann, T. Fearful or functional-a cross-sectional sur-vey of the concepts of childhood fever among German and Turkish mothers in Germany. BMC Pediatr. 2011, 11, 41. [CrossRef] [PubMed]

11. Schmitt, B.D. Fever phobia: Misconceptions of parents about fevers. Am. J. Dis. Child 1980, 134, 176-181. [CrossRef] [PubMed]

12. Sarrell, M.; Cohen, H.A.; Kahan, E. Physicians', nurses', and parents' attitudes to and knowledge about fever in early childhood. Patient Educ. Couns. 2002, 46, 61-65. [CrossRef]

13. Karwowska, A.; Nijssen-Jordan, C.; Johnson, D.; Dele Davies, H. Parental and health care provider understanding of childhood fever: A Canadian perspective. CJEM 2002, 4, 394-400. [CrossRef]

14. Al-Eissa, Y.A.; Al-Zaben, A.A.; Al-Wakeel, A.S.; Al-Alola, S.A.; Al-Shaalan, M.A.; Al-Amir, A.A.; Al-Shamsan, L.A. Physi-cian's perceptions of fever in children facts and myths. Saudi Med. J. 2001, 22, 124-128. [PubMed]

15. National Institute for Health and Clinical Excellence. Feverish Illness in Children-Assessment and Initial Management in Children Younger than 5 Years. 2013. Available online: https://www.nice.org.uk/guidance/cg160/resources/fever-in-under-5sassessment-and-initial-management-pdf-35109685049029 (accessed on 10 April 2019).

16. Community Paediatrics Committee. Fever and Temperature Taking. 2015. Available online: http://www.caringforkids.cps.ca/ handouts/fever_and_temperature_taking (accessed on 9 April 2019).

17. Alateeq, M.M.; Albader, B.O.; Al-Howti, S.Y.; Alsharyoufi, M.; Abdullah, J.B. Parent's knowledge and practice in home management of fever in their children in Riyadh, Saudi Arabia. J. Fam. Med. Prim. Care 2018, 7, 1012-1018.

18. Hussain, S.M.; Al-Wutayd, O.; Aldosary, A.H.; Al-Nafeesah, A.; AlE'ed, A.; Alyahya, M.S.; Alfeneekh, A.S.; Alkadi, S.A.; Alghasham, G.A.; Aloyaidi, G.A. Knowledge, Attitude, and Practice in Management of Childhood Fever Among Saudi Parents. Glob. Pediatr. Health 2020, 7. [CrossRef] [PubMed]

19. Ward, M.A. Patient education: Fever in children (Beyond the Basics). In UpToDate; Post, T., Ed.; UpToDate: Waltham, MA, USA, 2019; Available online: www.uptodate.com (accessed on 15 April 2019).

20. Athamneh, L.; El-Mughrabi, M.; Athamneh, M.; Essien, E.J.; Abughosh, S. Parents' Knowledge, attitudes and beliefs of Childhood fever management in Jordan: A Cross-Sectional Study. J. Appl. Res. Child. 2014, 5, 8.

21. DeGroot, A.; Dannenburg, L.; Vanhell, J. Forward and Backward Word Translation by Bilinguals. J. Mem. Lang. 1994, 33, 600-629. [CrossRef]

22. Raosoft. Sample Size Calculator. Available online: http:/ / www.raosoft.com/samplesize.html (accessed on 17 September 2020).

23. Eysenbach, G. Improving the quality of Web surveys: The Checklist for reporting results of internet E-Surveys (CHERRIES). J. Med. Internet Res. 2004, 6, e34. [CrossRef]

24. Osborne, J. Best Practices in Data Cleaning: A Complete Guide to Everything You Need to Do before and after Collecting Your Data; SAGE Publications Ltd.: Los Angeles, CA, USA; London, UK; New Delhi, India, 2013.

25. Arica, S.G.; Arica, V.; Onur, H.; Gülbayzar, S.; Dă̆, H.; Obut, Ö. Knowledge, attitude and response of mothers about fever in their children. Emerg. Med. J. 2012, 29, e4. [CrossRef] [PubMed]

26. Al-Eissa, Y.A.; Al-Sani, A.M.; Al-Alola, S.A.; Al-Shaalan, M.A.; Ghazal, S.S.; Al-Harb, A.H.; Al-Wakeel, A.S. Parental perceptions of fever in children. Ann. Saudi Med. 2000, 20, 202-205. [CrossRef]

27. Chiappini, E.; Principi, N.; Longhi, R.; Tovo, P.A.; Becherucci, P.; Bonsignori, F.; Esposito, S.; Festini, F.; Galli, L.; Lucchesi, B.; et al. Management of fever in chil-dren: Summary of the Italian Pediatric Society guidelines. Clin. Ther. 2009, 31, 1826-1843. [CrossRef]

28. Chiappini, E.; Venturini, E.; Remaschi, G.; Principi, N.; Longhi, R.; Tovo, P.A.; Becherucci, P.; Bonsignori, F.; Esposito, S.; Festini, F.; et al. 2016 Update of the Italian Pediatric Society guidelines for man-agement of fever in children. J. Pediatr. 2017, 180, e1. [CrossRef]

29. Chiappini, E.; Parretti, A.; Becherucci, P.; Pierattelli, M.; Bonsignori, F.; Galli, L.; de Martino, M. Parental and medical knowledge and management of fever in Italian pre-school children. BMC Pediatr. 2012, 12, 97. [CrossRef] [PubMed]

30. Morley, C.J. Measuring infants' temperature. Midwives Chron. 1992, 105, 26-29. [PubMed]

31. Chaturvedi, D.; Vilhekar, K.Y.; Chaturvedi, P.; Bharambe, M.S. Comparison of axillary temperature with rectal or oral temperature and determination of optimum placement time in children. Indian Pediatr. 2004, 41, 600-603. [PubMed]

32. El-Radhi, A.S.; Barry, W. Thermometry in paediatric practice. Arch. Dis. Child. 2006, 91, 351-356. [CrossRef] [PubMed]

33. Martin, S.A.; Kline, A.M. Can There Be a Standard for Temperature Measurement in the Pediatric Intensive Care Unit? AACN Clin. Issues Adv. Pr. Acute Crit. Care 2004, 15, 254-266. [CrossRef]

34. Nimah, M.M.; Bshesh, K.; Callahan, J.D.; Jacobs, B.R. Infrared tympanic thermometry in comparison with other temperature measurement techniques in febrile children. Pediatr. Crit. Care Med. 2006, 7, 48-55. [CrossRef]

35. Robinson, L.J.; Jou, H.; Spady, D.W. Accuracy of parents in measuring body temperature with a tympanic thermometer. BMC Fam. Pract. 2005, 6, 3-10. [CrossRef]

36. Chiappini, E.; Bortone, B.; Galli, L.; de Martino, M. Guidelines for the symptomatic management of fever in children: System-atic review of the literature and quality appraisal with AGREE II. BMJ Open 2017, 7, e015404. [CrossRef]

37. Al Rasheed, A.; Yagoub, U.; Alkhashan, H.; Abdelhay, O.; Alawwad, A.; Al Aboud, A.; Al Battal, S. Prevalence and predictors of self-medication with antibiotics in Al Wazarat Health Center, Riyadh City, KSA. BioMed Res. Int. 2016, 2016, 3916874. [CrossRef] 
38. Alghadeer, S.; Aljuaydi, K.; Babelghaith, S.; Alhammad, A.; Alarifi, M.N. Self-medication with antibiotics in Saudi Arabia. Saudi Pharm. J. 2018, 26, 719-724. [CrossRef] [PubMed]

39. World Health Organization. WHO Country Cooperation Strategy at a Glance: Saudi Arabia. World Health Organization. 2017. Available online: https:/ / apps.who.int/iris/handle/10665/136842 (accessed on 13 May 2021).

40. Saudi Arabia Social Media Statistics. 2018. Available online: https://www.globalmediainsight.com/blog/saudi-arabia-socialmedia-statistics / (accessed on 13 May 2021). 